\title{
Mikołaj Ratajczak
}

\section{Wielość: produkcja wspólnotowości}

Wraz z rozwojem technologicznym i postępem globalizacji coraz wyraźniejsze staje się gruntowne rozejście się rzeczywistości z przekazanym zasobem pojęć i teorii filozoficznych. Ten swoisty kryzys dotyka przede wszystkim filozofię polityczną, która zawsze starała się zawrzeć w sobie dwa momenty myślenia: postawienie diagnozy oraz perspektywę działania. Podczas gdy słownik klasycznej teorii politycznej wciąż obecny jest w instytucjach publicznych, w prawie państwowym i międzynarodowym czy w zapisach traktatów, a także na ustach tych u władzy i tych na ulicy, transformacje rzeczywistości - tak na poziomie społecznym, jak i ekonomicznym, technologicznym etc. - wymagają nowych dyskursów i teorii. Tylko poprzez uchwycenie przez filozofię zasadniczych, ontologicznych wręcz przemian w tkance świata oraz odniesienie ich do słownika filozofii klasycznej, filozofia polityczna ma szansę dalej wypełniać swoje emancypacyjne powołanie.

Jednym z pojęć, które ma szansę sprostać w przyszłości tak trudnemu zadaniu, jest rozwijane obecnie przede wszystkim w myśli włoskiej pojęcie wielości, multitudo. Związani w przeszłości z nurtem pozaparlamentarnej włoskiej lewicy myśliciele tacy jak Antonio Negri oraz Paolo Virno aplikują ten termin do analiz nowego podmiotu zglobalizowanego świata: płynnej, zróżnicowanej, hybrydycznej siły roboczej, swego rodzaju proletariatu ponowoczesności. Celem niniejszego tekstu jest zakreślenie perspektyw, które myśleniu filozoficznemu oferuje pojęcie wielości, przede wszystkim w tej postaci, w jakiej w książkach pisanych wespół z amerykańskim fillozofem Michaelem Hardtem rozwinął je Negri. Postaram się pokazać, w jaki sposób pojęcie to zarówno odnosi się do wybranych dyskursów klasycznej filozofii polityki, jak i obejmuje podmiot nowych form pracy i produkcji. Naczelnym zadaniem, jakie sobie stawiam, jest ukazanie zmiany w myśleniu o polityce i partycypacji w niej, jaką wymusza na nas przyjęcie perspektywy opracowywanej przez wyżej wymienionych filozofów. W tym celu wprowadzę na końcu tekstu rozróżnienie na wspólnotowość jako ontologiczny plan wielości, sieć przepływu symboli i afektów współtworzoną przez samą wielość, oraz wspólnotę jako konkretną aktualizację możliwości tkwiących w tej sieci.

Wszelka analiza musi jednak nieustannie dokonywać autorefleksji nad perspektywą z której wychodzi. Zwłaszcza współczesna filozofia polityczna musi zważać na pojawiające się w niej tendencje do uniwersalizacji twierdzeń oraz postulatów. Choć wielość jest podmiotem 
www.praktykateoretyczna.pl

obecnego etapu globalizacji, to trzeba pamiętać, że podobnie jak autonomistyczny nurt włoskiego marksizmu z lat siedemdziesiątych był - przy pełnej tego świadomości - ruchem możliwym tylko w rozwiniętych, „sytych” społeczeństwach, które najzwyczajniej w świecie mogły „pozwolić sobie” na luksus wolności od przymusowej pracy, tak samo omawiana w tym tekście teoria bazuje raczej na przemianach dokonujących się w tzw. świecie Zachodu ${ }^{1}$. $\mathrm{W}$ tle pozostaje jednak cały czas pytanie, do jakiego stopnia przemiany obserwowane przez nas w krajach rozwiniętych czy „rozwijających się” są paradygmatyczne dla kierunku przemian $\mathrm{w}$ skali globalnej $\mathrm{i}$ na ile wydarzenia $\mathrm{w}$ innych regionach świata mogą być interpretowane w optyce omawianej teorii.

\section{Wylania się wielość}

W kwietniu 1989 roku na Placu Niebiańskiego Spokoju (Tian’anmen) masowo zebrali się studenci, po to, by uczcić pamięć zmarłego dwa dni wcześniej Hu Yaobanga. Wkrótce poparli ich pekińscy robotnicy, a po upływie miesiąca trzy czwarte mieszkańców Północnej Stolicy. 20 maja w stolicy Chińskiej Republiki Ludowej wprowadzono stan wyjatkowy. Władza, powołując się na niedawne wydarzenia w Polsce i bojąc się eskalacji protestu, podjęła decyzję o użyciu siły. W nocy z 3 na 4 czerwca czołgi otworzyły ogień do studentów. Reakcja władz partii komunistycznej wydaje się całkowicie niewspółmierna do formy, jaką przybrał protest studentów i mieszkańców Pekinu. Być może rację ma Giorgio Agamben, gdy pisze, że „na placu Tian’anmen państwo zmierzyło się nagle z czymś, co nie chciało i nie mogło chcieć być reprezentowane, lecz co niemniej prezentowało sobą wspólnotę i wspólnotowe życie (i to niezależnie od tego, czy ci na placu byli tego naprawdę świadomi)"².

Tian'anmen był pierwszy. Od masakry studentów przez chińskie wojsko i upadku muru berlińskiego, przez świat przetoczyła się fala nowych protestów i powstań, które poddając się logice globalizacji, potrafiły doskonale się w tej zglobalizowanej rzeczywistości odnaleźć. Nie tyle podnoszone hasła, co forma, jaką protesty te przyjmowały, oraz położenie społeczne ich uczestników zwracały uwagę na przemiany zachodzące na świecie wraz z początkiem lat dziewięćdziesiątych. W 1992 roku w Los Angeles doszło do największych zamieszek, jakie miały miejsce w USA w dwudziestym wieku. Uwydatniły one wzajemne powiązanie powolnego zaniku fordystycznego modelu zarządzania produkcją kryzysu

\footnotetext{
${ }^{1}$ Zob. S. Lotringer, We, the Multitude, [przedmowa w:] P. Virno, A Grammar of the Multitude, thum. I. Bertoletti, J. Cascaito, A. Casson, New York 2004, s. 17.

${ }^{2}$ G. Agamben, Marginal Notes on „, Commentaries on the Society of the Spectacle”, [w:] tegoż, Means without End: Notes on Politics, thum. V. Binetti, C. Casarino, Minneapolis 2000, s. 89.
} 
technik społecznych mediacji, problemu wielkich, przeludnionych, multikulturowych metropolii oraz nowych sposobów funkcjonowania policji.

1 stycznia 1994 roku, gdy podpisane zostało porozumienie o wolnym handlu między krajami Ameryki Północnej (NAFTA), świat po raz pierwszy usłyszał o zapatystach. W stanie Chiapas, jednym z najuboższych regionów Meksyku, Zapatystowska Armia Wyzwolenia Narodowego rzuciła wyzwanie rządowi meksykańskiemu. W niezwykle krótkim czasie zapatyści przekształcili się $\mathrm{w}$ organizację, która za cel stawia sobie jedynie walkę o autonomię dla południowych stanów Meksyku, dbając o redystrybucję wśród lokalnych mieszkańców dóbr produkowanych dzięki tamtejszej ziemi. Poparcie dla swojej sprawy zyskują na całym świecie, przenosząc centrum walk do globalnej sieci. Korzystając z nowych narzędzi komunikacji, przede wszystkim z Internetu, pozostają w nieustannym kontakcie z przeróżnymi organizacjami alterglobalistycznymi i tworzą tym samym nowy, nieznany wcześniej model oporu³.

30 listopada („N30”) 1999 roku w Seattle odbyła się konferencja Światowej Organizacji Handlu (WTO). Tego samego dnia na ulicach miasta rozpoczęły się zamieszki, w których wzięło udział od 50 do nawet 100 tysięcy ludzi - od ugrupowań skrajnie prawicowych, przez organizacje katolickie, po różnego rodzaju organizacje pozarządowe, stowarzyszenia, ruchy alterglobalistyczne, lewicowe, ekologiczne i anarchistyczne. Dwa lata później w Genewie dwudziesty siódmy szczyt G8 zgromadził 200 tysięcy protestujących. Podobnie jak w wypadku Seattle, jednoznaczne określenie ich przynależności narodowościowej, klasowej czy ideologicznej (poza ogólnym i niewiele mówiącym określeniem ,alterglobalizm”) byłoby czymś niemożliwym.

Wydarzenia te są jednymi z wielu (strajki we Francji w 1995 roku oraz w Korei Południowej w 1996 roku, dwie intifady itd.), które począwszy od 1989 roku wstrząsały naszym zglobalizowanym światem ${ }^{4}$. Jako symptomy pewnych określonych procesów, pojawiają się one na kartach książek Hardta oraz Negriego - książek, których globalny zasięg oddziaływania porównać można z globalnym wymiarem opisywanych w nich zjawisk.

\footnotetext{
${ }^{3}$ Mihalis Mentinis w swojej książce Zapatistas: The Chiapas Revolt and What It Meant for Radical Politics (London 2006) do opisu specyfiki ruchu zapatystów używa pojęć zaczerpniętych ze współczesnych teorii polityki, m.in. teorii Ernesta Laclau oraz tradycji marksizmu autonomicznego, perspektywy Hardta i Negriego rozwiniętej w ich Imperium oraz filozofii Alana Badiou, takich jak: władza konstytuująca, „Imperium” jako nowy, międzynarodowy porządek, wierność wydarzeniu czy podmiotowość bojownika.

${ }^{4}$ Skupiam się w tym rozdziale wyłącznie na wydarzeniach, które pojawiają się w książkach Hardta i Negriego do roku 2005 (rok wydania Multitude). Wśród ważnych wydarzeń, które potwierdzałyby tezy obu filozofów na temat wewnętrznych procesów współczesnych społeczeństw, należałoby dzisiaj wymienić także odbywające się od roku 2009 masowe strajki studentów: od Santa Cruz po uniwersytety niemieckie. Zob. Communiqué z nieobecnej przyszłości - o kresie życia studenckiego w tym numerze „Praktyki Teoretycznej”.
} 
Wspólna praca Hardta i Negriego zapoczątkowana została tomem pt. Labor of Dionysus ${ }^{5}$, światowy rozgłos uzyskała jednak dopiero ich druga wspólna książka, Imperium ${ }^{6}$, która wraz z pozycją będącą jej kontynuacją - Multitude ${ }^{7}$ - proponuje zestaw teoretycznych utensyliów, mających służyć interpretacji obecnego etapu postępującej globalizacji, na poziomie zarówno instytucjonalnym, prawnym, politycznym, ekonomicznym, jak i filozoficznym, albo (mówiąc językiem autorów) biopolitycznym, czyli obejmującym wszelkie aspekty życia ludzi we współczesnym świecie. Tak obszernego, interdyscyplinarnego podejścia wymaga sam przedmiot zainteresowania obu myślicieli, jako że omawiane przez nich ,walki [...] są jednocześnie ekonomiczne, polityczne i kulturowe - i stąd są walkami biopolitycznymi, walkami o formę życia"8.

\section{Od dyscypliny do kontroli}

Jednocześnie $z$ transformacjami form protestów i walk toczonych o nowe wizje wspólnotowości, swoistą rewolucję przeżywała (i dalej przeżywa) materialna baza społeczeństw dojrzałej globalizacji. Rewolucja, której tempo dziś wcale nie osłabło, przebiega pod szyldem informatyzacji, dematerializacji produkcji oraz rozwoju sieci komunikacji, będąc tym samym warunkiem nowego oblicza ruchów społecznych. Hardt i Negri wspominają, że rozpoczęli pisanie Imperium w okresie pierwszej wojny w Zatoce Perskiej ${ }^{9}$. „Pustynna burza", na co uwagę zwrócił już Jean Baudrillard ${ }^{10}$, była pierwszym konfliktem ukazującym nową potęgę mediów, a także bezprecedensowe możliwości przepływu informacji. Ruchy demokratyczne szybko nauczyły się wykorzystywać nowe technologie - gdyby nie Internet, nie byłoby N30 w Seattle, a zapatyści byliby dzisiaj prawdopodobnie zupełnie inną organizacją.

Wojna w Zatoce Perskiej (oraz późniejsze interwencje zbrojne, tak USA, jak i różnych organizacji międzynarodowych) z jednej strony i globalne ruchy alterglobalistyczne z drugiej są przykładami tego, w jaki sposób rewolucja technologiczna wytworzyła zarówno nowy mechanizm władzy - to, co Hardt i Negri nazywają „Imperium”, jak i przeciwstawiający się

\footnotetext{
${ }^{5}$ M. Hardt, A. Negri, Labor of Dionysus: a Critique of the State-Form, Minneapolis 1994.

${ }^{6}$ Tychże, Imperium, tłum. A. Kołbaniuk, S. Ślusarski, Warszawa 2005 (oryginał ukazał się w 2000 roku).

${ }^{7}$ Tychże, Multitude: War and Democracy in the Age of Empire, London 2005.

${ }^{8}$ Tychże, Imperium, s. 72.

${ }^{9}$ Tamże, s. 13.

${ }^{10}$ J. Baudrillard, Wojny w Zatoce nie było, tłum. S. Królak, Warszawa 2006.
} 
mu podmiot demokratycznych dążeń i sprzeciwu wobec władzy - wielość ${ }^{11}$. Transformacje mechanizmów kontroli oraz dyscyplinowania społeczeństwa są procesami paralelnymi wobec wykształcania się nowych form oporu oraz powstawania podmiotów będących w stanie przeciwstawić się tym mechanizmom. Przemiany globalne - powstawanie Imperium posiadają oczywiście swoje odpowiedniki na poziomie lokalnym, poziomie dyscyplinowania umysłów umiejscowionych w konkretnych ciałach. Chodzi o proces, który Gilles Deleuze za Michelem Foucaultem nazywa przejściem od społeczeństwa dyscypliny do społeczeństwa kontroli $^{12}$. Przejście to charakteryzuje się powolnym zanikiem paradygmatu wytwarzania podmiotowości oraz sprawowania kontroli nad nią $w$ zamkniętych instytucjach oddzielonych od siebie rodzinie, szkole, fabryce, szpitalu, więzieniu itd. Zamiast tego powstają formy organizacji, które powodują przenikanie się niegdyś oddzielonych od siebie obszarów społecznych. „Zamknięcia to odrębne formy odlewnicze, podczas gdy mechanizmy kontroli są modulacja, czymś w rodzaju samoczynnie odkształcającej się formy, podlegającej ciagłym przemianom, albo sita, którego dziurki stale zmieniałyby wielkość"13. Dla Deleuze’a najważniejszym przykładem przejścia od starych urządzeń dyscypliny do form dostosowanych w dzisiejszej, płynnej rzeczywistości kapitału jest zanik fabryki na korzyść przedsiębiorstwa. W ramach organizacji pracy w fabryce wyzysk polegał po prostu na wydłużaniu dnia pracy (ewentualnie obniżce płacy), a jasna opozycja tych, którzy pracowali i tych, którzy posiadali oraz sama forma wykonywanych zadań prowadziły do przekształcania grupy poddawanej dyscyplinie w jednolite ciało - żywe i pracujące (co było na rękę zarazem pracodawcom, jak i związkom zawodowym, ponieważ umożliwiało łatwą mobilizację siły roboczej, czy to do pracy, czy strajku) ${ }^{14}$. „Społeczeństwo dyscyplinujące jest więc społeczeństwem na wzór fabryczny"15, podczas gdy w społeczeństwie kontroli fabryka ustępuje miejsca przedsiębiorstwu, które zatrudnia pracowników mocno zindywidualizowanych, nieustannie kształconych i szkolonych. Przedsiębiorstwo ma więc w sobie coś z rodziny - bazuje na afektywnych relacjach między ludźmi, coś ze szkoły nieustannie kształci, rozwija jednostkę, a także coś ze współczesnego szpitala i więzienia (z właściwymi dla tych przestrzeni formami upodmiotowienia).

\footnotetext{
${ }^{11}$ Używane przez Hardta i Negriego pojęcie multitude, które w języku włoskim brzmi multitudo, oddaję w tym tekście jako „wielość”, wbrew polskim tłumaczom Imperium, którzy zdecydowali się na, być może historycznofilozoficznie właściwszy, ale obciążony zbyt wieloma negatywnymi konotacjami termin „rzesza”. Zob. Imperium, s. 12, przypis thumaczy.

${ }^{12}$ G. Deleuze, Postscriptum o społeczeństwie kontroli, [w:] tegoż, Negocjacje: 1972-1990, tłum. M. Herer, Wrocław 2007.

${ }^{13}$ Tamże, s. 184.

14 Tamże, s. 185.

${ }^{15}$ M. Hardt, A. Negri, Imperium, s. 263.
} 
www.praktykateoretyczna.pl

Diagnozując za Deleuzem ten sam proces przejścia do nowego paradygmatu władzy, który nazywają przejściem od imperializmu do Imperium, Hardt i Negri starają się wyjaśnić zachodzące transformacje za pomocą pojęcia korupcji, inspirując się przy tym analizami korupcji imperium obecnymi u klasycznych filozofów polityki, zwłaszcza u Niccolò Machiavellego $^{16}$. Jednym z symptomów wszechobecnej dziś korupcji jest to, że „Imperium nie osiaga żadnej czystej postaci"17, tzn. że żadna $\mathrm{z}$ instytucji, które wytwarzały podmiotowości w epoce nowożytnej (społeczeństwie dyscypliny) nie funkcjonuje już jako autonomiczna sfera, niezależna forma odlewnicza. Wielość jest pojęciem odnoszącym się do podmiotowości powstających wśród tych zdecentralizowanych i skorumpowanych instytucji, w nie-miejscu (miejscu niemożliwym do jednoznacznego zlokalizowania: wszędzie i nigdzie) władzy, wyzysku i produkcji.

Deleuze kreśli relację między dwoma typami społeczeństw a charakterystycznymi dla każdego z nich maszynami ${ }^{18}$. Jeśli dla społeczeństwa dyscyplinarnego naczelną jednostką organizacji pracy była fabryka, to maszyna, którą to społeczeństwo masowo się posługuje, będzie zindustrializowaną, wielką maszyną fabryczną („energetyczną”, korzystając z określenia Deleuze’a), która niczym „Moloch” ze słynnego Metropolis pożera ciała pracujących przy niej ludzi (pozostając podatną na fizyczny sabotaż). Charakterystyczną dla społeczeństwa kontroli będzie odpowiednio maszyna informatyczna, oparta na analizie symboli i przesyłaniu informacji w postaci cyfrowej. Hardt i Negri skupiają się na tym aspekcie filozofii Deleuze'a (zawartym przede wszystkim w jego pracach pisanych wraz z Feliksem Guattarim), który łączy maszyny z produkcją społeczną, z maszynami społecznymi: „Produkcja ta jest dziełem machin. Stałe funkcjonowanie machin społecznych, w ich różnych aparatach i zestawach, produkuje świat wraz $\mathrm{z}$ podmiotami i przedmiotami, które go konstytuują"19. Społeczeństwo kontroli, zbudowane zatem na mechanizmach i trybach (czy raczej układach scalonych) machin informatycznych współkonstytuujących plan konsystencji ${ }^{20}$ współczesnych maszyn społecznych, żyć będzie innego rodzaju pracą niż społeczeństwa dyscyplinarne, wznoszone mięśniami robotników fabrycznych.

\footnotetext{
16 Tamże, s. 213-220, 409-412.

17 Tamże, s. 220.

${ }^{18}$ G. Deleuze, Postscriptum..., s. 186.

${ }^{19}$ M. Hardt, A. Negri, Imperium, s. 43.

20 „Plan konsystencji maszynowej” to pojęcie rozwijane przede wszystkim przez Guattariego w jego maszynizmie społecznym. Odnosi się do abstrakcyjnego momentu powiązania różnego rodzaju maszyn regulujących użycie znaków, przepływ ciał, materii, użycia obiektów etc. Na planie konsystencji formułuje się „maszyna abstrakcyjna”, matryca wiązania systemów znaku i przepływów intensywności.. Zob. M. Herer, Gilles Deleuze: struktury-maszyny-kreacje, Kraków 2006, s. 114-116. Kapitalizm, który był w stanie doprowadzić do realnej subsumcji społeczeństwa pod swoją zasadę, jest w tym sensie planem konsystencji o najwyższym stopniu abstrakcji.
} 
Dalej postaram się zrekonstruować relację, jaką Hardt, Negri oraz Virno widzą między nowymi formami produkcji (pracą niematerialną) a biopolityczną konstytucją wielości. W tym celu postaram się zarysować różnicę między wielością a przekazanymi nam przez tradycję figurami podmiotu polityki: ludu, narodu, klasy. W wypadku tej ostatniej kategorii nakreślę przejście od charakterystycznego dla dziewiętnastowiecznego kapitalizmu modelu robotnika wykwalifikowanego, przez masowego robotnika epoki fordyzmu, aż do podmiotu (czasami jednak wciąż po-miotu) postfordowskiego reżimu produkcji, „robotnika społecznego", będącego innym imieniem wielości. W tym celu zrekonstruuję relacje, jakie zachodzą między dematerializacją pracy, informatyzacją oraz biopolitycznym wytwarzaniem podmiotowości.

\section{Czym jest wielość?}

Wielość (łac. multitudo) nie jest oczywiście terminem ukutym przez filozofów współczesności. Używał go już Cyceron, gdy w De Re Publica pisał o początku i źródle republiki ${ }^{21}$. Pojęcie to pojawia się także w dziele De monarchia ${ }^{22}$ Dantego oraz w pismach Machiavellego $^{23}$. W filozofii nowożytnej multitudo odegrało istotną rolę w dyskusji między Thomasem Hobbesem a Baruchem Spinozą o formie nowoczesnego państwa i jego relacji ze społeczeństwem. Kiedy pojęcie to przejęli intelektualiści wywodzący się z włoskiego ruchu Operaismo, dokonali mariażu funkcji, jaką multitudo odgrywało w klasycznej filozofii polityki, z wątkami zaczerpniętymi z myśli marksistowskiej oraz francuskiego poststrukturalizmu. Dlatego mówiąc o „wielości” w kontekście myśli postoperaistycznej, należy brać pod uwagę trzy poziomy analizy tego terminu ${ }^{24}$ :

1. Wielość widziana jako podmiot polityki w sensie tradycyjnym. Zestawia się ją tu $\mathrm{z}$ kategoriami budującymi nowożytną teorię polityki i państwa, takimi jak lud czy naród.

2. Wielość jako podmiot procesów produkcji, a tym samym żywa praca poddana wyzyskowi. Doświadczenie wyzysku dzieli z innym pojęciem nowożytnej teorii polityki, klasą, różniąc się jednak od niej w byciu otwartą na wszelkie formy produkcji (wszelkie formy życia).

\footnotetext{
${ }^{21}$ Marek Tuliusz Cyceron, O państwie. O prawach, tłum. Iwona Żółtowska, Kęty 1999.

${ }^{22}$ Dante Alighieri, On World-Government, tłum. H. W. Schneider, New York 1957.

${ }^{23}$ N. Macchiavelli, Discorsi Sopra la Prima Deca di Tito Livio, Torino 1993. Zob. też P. Christofolini, Populus, Plebs, Multitudo: Nota Lessicale su Alcuni interscambi e Fluttuazioni di Significato da Livio e Macchiavelli a Spinoza, "Laboratorio dell'ISPF" 2008, $\mathrm{nr}$ 1, s. 27-31. Tekst dostępny na stronie http://www.ispf.cnr.it/file.php?file=/ispf_lab/documenti/multitudo_cristofolini.pdf.

24 A. Negri, Powrót: alfabet biopolityczny, tłum. M. Żakowski, Warszawa 2006, s. 103-104.
} 
www.praktykateoretyczna.pl

3. Wielość jako dysponentka konstytutywnej mocy tworzenia rzeczywistości, stająca się dzięki temu kategorią ontologiczną, która wytwarza całą rzeczywistość społeczną jako taką, będąc jednocześnie przeciwstawioną władzy (pojmowanej jako moc negatywna).

Żaden z wyróżnionych poziomów nie jest oczywiście odizolowany od pozostałych, a samo wyróżnienie jest zabiegiem wynikającym raczej z uwarunkowań metod analizy pojęciowej, niż z natury samego przedmiotu rozważań. Pojęcie klasy (drugi poziom) pozostaje w związku z terminologią klasycznej filozofii polityki (pierwszy poziom). Słowo die Klasse, którym posługiwał się Karl Marks, będące w istocie galicyzmem ${ }^{25}$, miało zastąpić Heglowskie pojęcie der Stand i tym samym przekroczyć transcendentalną teorię społeczeństwa (która stanowiła swoistą rekapitulację nowożytnej teorii państwa i demokracji, od Hobbesa do Jeana Jacquesa Rousseau i Immanuela Kanta). Podział klasowy społeczeństwa europejskiego pojawił się $\mathrm{w}$ filozofii w momencie, w którym nowoczesny porządek polityczny zaczynał chwiać się w posadach, podtrzymywany jedynie mocą gigantycznych dziewiętnastowiecznych aparatów państwowych. Klasa jako kategoria filozofii politycznej pełni zatem funkcję krytyczną wobec przekazanych przez tradycję pojęć narodu i ludu (podstaw koncepcji suwerenności państwa) oraz stanu (podstawy hierarchizującej struktury nowoczesnego społeczeństwa), wskazując na czynniki ekonomiczne jako determinujące (czy raczej, jakby to ujął Louis Althusser, naddeterminujące ${ }^{26}$ ) kategorie społeczne. Wyróżnienie trzeciego, ontologicznego poziomu analizy jest konsekwencją przemian w procesach produkcji, których diagnoza jest jednym z filarów całego projektu filozoficzno-politycznego Hardta i Negriego. Na początku dwudziestego pierwszego wieku rzeczywistość wygląda zupełnie inaczej niż za czasów, gdy pojęcie klasy w jej relacji ze święcącym triumfy kapitalizmem opisywał Marks: żyjemy dziś w zglobalizowanym społeczeństwie informacji, gdzie hegemoniczną formą pracy jest praca oparta o sieci komunikacji, przetwarzanie symboli i analizowanie danych (dematerializacja produkcji). By pokazać, w jaki sposób przemiany te wymusiły wprowadzenie ontologicznego poziomu analizy wielości, należałoby przywołać pojęcie biopolityki (a także biowładzy). W dalszych partiach tekstu skupię się jedynie na pierwszych dwóch wymienianych przez Negriego poziomach, starając się jednocześnie pokazać, $\mathrm{w}$ jaki sposób powiązanie $\mathrm{w}$ jego pismach pojęcia pracy niematerialnej oraz biopolityki umożliwia przejście na trzeci - zdaje się najważniejszy - poziom myślenia o

25 Tym samym pojawienie się terminu die Klasse w pismach Marksa jest jednym z pierwszych przejawów tego, co uczyni je tak interesującymi pod względem językowym: rozkładu czystej niemczyzny na korzyść hybrydy wielu języków.

${ }^{26}$ Zob. L. Althusser, Sprzeczność i naddeterminacja: notatki do przyszlych badań, [w:] tegoż, W imię Marksa, thum. M. Herer, wstęp A. Ostolski, Warszawa 2009, s. 111-143. 
wielości jako podmiocie społecznym ${ }^{27}$. Postaram się również zachować funkcjonujące w pismach autorów Multitude rozróżnienie na wielość sub specie aeternitatis (wielość jako abstrakcyjną ideę i jako nowe ujęcie relacji jednego do wielu) oraz na wielość jako podmiot przemian historycznych, twór konkretnych procesów produkcji i aktywności politycznej:

Ta pierwsza wielość jest ontologiczna i nie bylibyśmy w stanie wyobrazić sobie bez niej naszego bytu społecznego. Druga jest wielością historyczną, albo inaczej mówiąc, jeszcze-nie wielością. Ta wielość jeszcze nigdy nie zaistniała ${ }^{28}$.

Niezwykle trudno zbudować spójny dyskurs o wielości, który nie polegałby jedynie na mówieniu, czym ona nie jest (ani lud, ani naród, ani klasa). Jeśli chcielibyśmy wskazać, kto, lub raczej co tworzy wielość, należałoby prawdopodobnie powtórzyć za Edwinem Bendykiem (wielokrotnie odwołującym się do Hardta i Negriego), że wielość to

różnorodność zindywidualizowanych i niepowtarzalnych jednostek, których pojedyncze głosy nie dadzą się wyartykułować w postaci jednego, abstrakcyjnego, wspólnego głosu. Multitudo nie zna hierarchii, ma strukturę sieciową, skupia zarówno biednych tego świata, jak i wykorzystywany w cyfrowych sweatshopach wysoko wykwalifikowany digitariat ${ }^{29}$.

Jeśli tylko przyjrzymy się jednostkom, które współtworzą ten dziwny twór, to zaobserwujemy dwie tendencje odróżniające ten typ wspólnotowego życia od klasycznych form społecznych:

1. Globalna sieć komunikacji umożliwia zawiązywanie wspólnotowych relacji ponad narzuconymi przez historię liniami podziałów. Tendencja ta idzie oczywiście w parze z przebiegającymi w strukturach Imperium procesami globalizacji przepływu symboli i „tradycji” (deterytorializacja) oraz wytwarzania lokalności (reterytorializacja). Mówiąc krótko: ponieważ relację tego, co lokalne, do tego, co globalne, należy tu rozumieć jako „pewien porządek produkcji tożsamości i różnicy, czyli w istocie homogenizacji i

\footnotetext{
${ }^{27}$ Poziom analizy ontologicznej wymaga odwołania się do strukturyzującej praktycznie całą filozofię Negriego opozycji władzy konstytuującej i ukonstytuowanej, rozwijanej przede wszystkim w jego Il potere constituente: Saggio Sulle Alterntive del Moderne, Carnago 1992 (tłum. ang. Insurgencies: Constituent Power and the Modern State, thum. M. Boscagli, Minneapolis 1999). Opozycja ta, jakkolwiek wydaje się być logiczną konsekwencją rozwijanego przez Negriego wespół z Hardtem ujęcia biopolityki, niesie ze sobą zbyt wiele problemów natury teoretycznej, by można ją wprowadzić do tego tekstu. W kwestii krytyki opozycji władzy konstytuującej/władzy ukonstytuowanej zob. G. Agamben, Homo sacer: suwerenna władza i nagie życie, thum. M. Salwa, posł. P. Nowak, Warszawa 2008, s. 65-67.

${ }^{28}$ M. Hardt, A. Negri, Multitude..., s. 218.

${ }^{29}$ E. Bendyk, Miłość, wojna, rewolucja: szkice na czas kryzysu, Warszawa 2009, s. 45.
} 
www.praktykateoretyczna.pl

heterogenizacji”30, ci, którzy uczestniczą w tej produkcji (wielość), korzystają z globalnej sieci, czując się zarazem coraz mniej przywiązanymi do symbolicznego wymiaru danej lokalności.

2. Jednocześnie Hardt i Negri usilnie podkreślają, że „globalny zasięg tego, co wspólne nie neguje pojedynczości nikogo $\mathrm{z}$ tych, którzy uczestniczą w sieci” ${ }^{\text {31 }}$. Zachowane zostaje dziedzictwo maja 1968 oraz teoretycznych batalii postmodernistów - walk o pluralistyczne społeczeństwo i uznanie dla odmiennych form życia. Wielość narracji czy szacunek dla innego zostają jednak wzbogacone o moment produkcji wspólnego życia, nadający każdej jednostce odebrany jej lub poważnie nadwątlony przez postmodernizm status podmiotu ucieleśnionego, produktywnego, wspólnotowego.

Wielość jest zbiorowością twórczych i komunikujących się podmiotów, które wytwarzaja się - by użyć tutaj tego paradoksalnego, lecz oddającego stan rzeczy wyrażenia na przecięciu obu tych tendencji (denaturalizującej globalizacji oraz nowych form produkcji podmiotów). Specyfika tego topologicznego usytuowania wielości skutkuje karnawałowym charakterem jej działań, jej aktywności: „Multitudo jest pełne sprzeczności, bo gdy działa, jak w Seattle w 1999, łączy w karnawałowym porywie ludzi o różnorodnych rodowodach"32. Właśnie dlatego, że dzisiejsze formy produkcji, którym przyjrzymy się niżej, polegają na produkcji dokładnie tego, co w przeszłości stanowiło przekaz tradycji, łączącej ludzi we wspólnoty (idee, języki, więzi emocjonalne), każdy podmiot wielości zarazem przeobraża symboliczne warunki, w których żyje, podążając za deterytorializującą mocą globalnych przepływów kapitału, jak i broni się przed narzucaną mu reterytorializacją symbolicznych tożsamości, produkując nieustannie nowe idee, symbole i znaczenia. Stare hierarchie i podziały przestają obowiązywać, a nowe napotykają na opór podmiotów, które według Hardta i Negriego są w stanie obyć się bez jakichkolwiek form zarządzania, czy to przez państwo, czy przez kapitał: „kapitał nie prezentuje się już w swojej funkcji organizowania siły roboczej, lecz raczej w roli przyjmowania i zarządzania autonomiczną samo-organizacją siły roboczej ${ }^{33}$.

Deterytorializująca moc wielości objawia się na wszystkich możliwych płaszczyznach, przez które przebiegają linie podziałów i hierarchii. Beatriz Preciado ukuła pojęcie ,polityki queerowej wielości” (la politique des multitudes queer), które wskazuje na radykalnie nieesencjalistyczne podejście do problematyki genderowej i queerowej, charakterystyczne dla

\footnotetext{
${ }^{30}$ M. Hardt, A. Negri, Imperium, 61.

${ }^{31}$ Tychże, Multitude..., s. 217.

${ }^{32}$ Tamże, s. 45.

${ }^{33}$ Tychże, Labor of Dionysus..., s. 278.
} 
perspektywy wychodzącej właśnie od pojęcia wielości. Podejście to odrzuca jakiekolwiek postawy zakładające bądź to biologiczne, bądź w jakkolwiek inny sposób esencjalizujące koncepcje czy to „różnicy seksualnej” czy „kobiety”, ,geja” itd. (jako przedstawicielki tego typu esencjalizujących teorii Preciado wymienia m.in. Luce Irigaray), jak również emancypacyjne cele polityczne dążące np. do „wyzwolenia kobiet spod męskiej dominacji”,34. Jak Bendyk widział wśród wielości jednostki różniące się od siebie statusem materialnym, wykształceniem oraz rodzajem wykonywanej pracy, tak Preciado znosi różnice na płaszczyźnie praktyk seksualnych, zaliczając do wielości „ruchy feministyczne, homoseksualne, transseksualne, interseksualne, transgatunkowe, chicanas, postkolonialne...". Podsumowując: „Mniejszości seksualne stają się wielością!”35. Nie chodzi o to, kim ktoś jest, lecz o konkretne praktyki, które wytwarzają tożsamości (deterytorializacja, opór wobec reterytorializacji).

\section{Poziom pierwszy: dialektyka nowoczesności}

Literacka figura karnawału, jaką znajdujemy w pismach Michaiła Bachtina, służy Hardtowi i Negriemu do ukazania dynamiki wielości, która wymyka się przekazanej przez nowożytność opozycji między suwerennością i anarchią ${ }^{36}$. Karnawałowa literatura nie musi być od razu literaturą śmiechu i zabawy, sugestywnie opisywaną przez François Rabelais'go literaturą ludowej szczęśliwości. Także pełna dramatyzmu i tragedii powieść Fiodora Dostojewskiego wpisuje się w nurt literatury karnawałowej, gdyż jej dialog nie rozwija jednej myśli, tak jak to dzieje się np. w powieści egzystencjalnej, lecz jest zderzeniem wielu niezależnych głosów, produkujących nową rzeczywistość. „W polifonicznej koncepcji narracji nie ma centrum, które dyktowałoby znaczenie, lecz powstaje ono raczej we wzajemnym dialogu pomiędzy wszystkimi pojedynczościami”37.

Karnawałowy charakter wielości ukazuje jej prawdziwie rewolucyjne oblicze. Tak jak W polilogicznej powieści narracja rozwijana jest $\mathrm{w}$ dialogu między wieloma pojedynczościami, którego nie można sprowadzić do żadnej dialektycznej figury, tak samo wielość organizuje się nie poprzez wypracowanie powszechnej woli wszystkich, lecz poprzez

\footnotetext{
${ }^{34}$ B. Preciado, Multitudes Queer: Notes pour Une Politique des Aanormaux, "Multitudes" 2003, nr 12, s. 6, http://multitudes.samizdat.net/Multitudes-queer (strony podaję według wydruku). Zainteresowanym relacją między koncepcją wielości a problematyką feministyczną, gender oraz queer polecam cały numer 12 czasopisma, poświęcony tej właśnie tematyce.

35 Tamże, s. 3.

${ }^{36}$ M. Hardt, A. Negri, Multitude..., s. 208.

${ }^{37}$ Tamże, s. 211.
} 
www.praktykateoretyczna.pl

komunikację w zdecentralizowanej sieci. Pojęcie wielości unika w ten sposób wspomnianej już alternatywy między anarchią a suwerennością, która dla Hobbesa stanowiła podstawę konstrukcji nowoczesnego porządku państwowego. Czy to w figurze Lewiatana, w woli powszechnej, czy w Heglowskiej wizji społeczeństwa obywatelskiego, które swoją istotę osiaga dopiero w państwie, nowoczesność wypierała pojęcie wielości, pojmując je jedynie jako niepoddającą się żadnej kontroli anarchię. Nie potrafiąc wyobrazić sobie porządku społecznego opartego na faktycznej różnorodności i wielości społecznych podmiotów, teoretycy nowoczesnego ładu konstruowali pojęcia dążące do zniesieniu pluralizmu wielości. Virno wskazuje jednak, że już u samego zarania nowoczesności istniał spór między wizją nowożytnej suwerenności - Hobbesowskiego Lewiatana, którego władza oparta była na powszechnej umowie społecznej - a prawdziwie demokratyczną wizją rozwijaną przez Spinozę, w której nie dochodziło do zniesienia różnorodności pojedynczych głosów ${ }^{38}$. Spór ten odsłonił alternatywę, w której jeden z jej członów - lud, który artykułował swoją powszechną wolę we wspólnym głosie, bądź też w wielości różnorodnych głosów - nie mógł istnieć obok drugiego. Z perspektywy Hobbesa wielość żyła w pierwotnym stanie natury, którego anarchiczność uniemożliwiała zaistnienie porządku społecznego. Musiała zatem ustapić miejsca ludowi, by ten z kolei przygotował grunt pod ukonstytuowanie się państwa (Lewiatana). Odrzucając pojęcie ludu i pozostając $w$ radykalnej immanencji charakterystycznej dla wielości, państwo ukazałoby brak swojego ufundowania. Zatem: albo lud-państwo, albo wielość-immanencja.

Hardt i Negri rozpisują ten proces konstytucji nowoczesności na trzy momenty:

1. rewolucyjne odkrycie sfery immanencji;

2. reakcja przeciwko siłom tej sfery;

3. częściowe i tymczasowe rozwiązanie konfliktu poprzez utworzenie państwa narodowego 39 .

Pojęcie immanencji, które pojawia się w tym kontekście jako ontologiczny plan konstytucji wielości, autorzy zapożyczyli - jak wiele innych terminów swego filozoficznego słownika - z filozofii Deleuze'a. Pominę jednak cały filozoficzny aspekt tego zapożyczenia ${ }^{40} \mathrm{i}$

\footnotetext{
${ }^{38}$ P. Virno, A Grammar of the Multitude, s. 21-22.

${ }^{39}$ M. Hardt, A. Negri, Imperium, s. 82.

${ }^{40}$ Negri w swoim poświęconym Mills Plateaux oraz Co to jest filozofia tekście, w którym pojawiają się figury i pojęcia wykorzystywane potem przez niego w książkach pisanych z Hardtem (m.in. pojęcie wielości), wskazuje na cztery najważniejsze jego zdaniem problemy teorii wypracowanej przez Deleuze'a razem z Guattarim: ekspresja, sieć lub kłącze, nomadologia oraz płaszczyzna, plateau. Zob. A. Negri, On Gilles Deleuze \& Félix Guattari: a Thousand Plateaus, tłum. Ch. T. Wolfe. Tłumaczenie udostępnione na stronie korotonomedya.net, http://korotonomedya.net/theoria/Negri_1000plateaus.html. Wszystkie cztery analizowane przez Negriego pojęcia z Mills Plateaux zbudują potem filozoficzny szkielet Imperium.
} 
zarysuję jedynie konsekwencje odkrycia immanencji jako konkretnego procesu historycznego, lokalizowanego w Europie między rokiem 1200 a $1600^{41}$. W filozoficznej rewolucji Dunsa Szkota, w ideale nauki eksperymentalnej, w nowych koncepcjach władzy u Christophera Marlowe'a, Dantego i Machiavellego, w renesansowym wyniesieniu człowieczego rozumu i zdolności kreacji do rangi boskiej siły działającej w świecie, Hardt i Negri widzą prawdziwie rewolucyjne przemiany świadomości jednostek. Owa rewolucyjność polegała na tym, ,że oto siły stworzenia, uprzednio przypisywane wyłącznie niebiosom, teraz ściagnnięto na ziemię"42. Idea immanencji jest odrzuceniem wszelkiej instancji upoważniającej człowieka do działania, zapośredniczającej jego możliwości w oddzielonej od niego, niezależnej sferze transcendencji.

Okres renesansu kończy się jednak krwawymi wojnami, które według autorów Multitude były reakcją na rewolucyjność odkrytej sfery immanencji. To właśnie w okresie wojny trzydziestoletniej rozwija się refleksja Hobbesa, który immanentnej mocy wielości przeciwstawi pojęcie ludu, zapośredniczonego w swojej aktywności w państwie-Lewiatanie. „Europejska nowoczesność jest od początku wojną na dwa fronty”43, stwierdzają Hardt i Negri, a oznacza to, że choć zarówno w filozofii, jak i w rzeczywistości renesansowe odkrycie sfery immanencji spotkało się z silnym oporem i brutalną reakcją, nie zostało ono całkowicie stłumione, lecz stało się jednym z filarów nowoczesności. Na płaszczyźnie filozoficznej zderzeniu sfery immanencji z siłami reakcji odpowiadał spór między Hobbesem a Spinozą, który swoje rozwiązanie znalazł w oświeceniowej filozofii prawa, zwłaszcza w niemieckim idealizmie: u Kanta i Hegla, którzy rozstrzygnęli konflikt na korzyść zwolenników władzy zwierzchniej. Transcendentność Lewiatana przekształcona zostaje w transcendentalne ugruntowanie prawa i państwa. W rozwijanej dalej przez Negriego terminologii Spinozy można by powiedzieć, że władza (potentia) wielości przeciwstawiona zostaje Władzy (potestas) państwa, a dialektyka tych dwóch sił swoje petryfikujące zapośredniczenie znajduje w Heglowskiej logice transcendentalnej i w opartej o nią teorii państwa. „Dialektyka narzuca transcendentalne wyparcie ciagłego konfliktu, jaki władzy ukonstytuowanej wypowiada kolektywna władza konstytuująca mas, wspólnotowej pracy”44. Czy to pomyślany jako transcendentna władza suwerena, czy jako transcendentalnie ugruntowany porządek prawny, nowożytny aparat państwowy ustanawia władzę ufundowaną na wspólnej, jednej woli ludu - i w dialektycznym zniesieniu wielości. Dwa filary

\footnotetext{
${ }^{41}$ M. Hardt, A. Negri, Imperium, s. 87.

${ }^{42}$ Tamże, s. 89.

43 Tamże, s. 93.

${ }^{44}$ Tychże, Labor of Dionysus..., s. 283.
} 
www.praktykateoretyczna.pl

nowoczesności to zatem z jednej strony ideał demokracji bezpośredniej, spinozjańska wizja wielości ustanawiającej rządy oparte na ideach samoorganizacji i samorządności, a z drugiej teoria władzy oparta na zapośredniczeniu ontologicznej mocy wielości w zewnętrznym wobec niej aparacie. Wielość odniesiona do tego aparatu przekształca się u Hobbesa w lud, a potem (zwłaszcza u myślicieli niemieckich) w naród.

Pojęcie narodu utrzymuje więc swego rodzaju naturalną ciagłość z ideą ludu. Wyzwolone przez nowoczesność procesy cyrkulacji pieniędzy i towarów (procesy deterytorializacji) oraz idee praworządnej władzy doprowadziły do trzech rewolucji burżuazyjnych (angielskiej, amerykańskiej i francuskiej), w wyniku których doszło jednak do nowej konstytucji i wzmocnienia całego aparatu państwowego w idei wspólnoty krwi, terytorium i tradycji, uzasadniających w swoim sprzężeniu suwerenność scentralizowanej władzy. Suwerenny model nowoczesnego państwa, następujący po nowożytnych rewolucjach, potrzebował silniejszego ugruntowania niż to, które ufundowane było na pojęciu ludu, gdyż sam powołany został do życia przez procesy zagrażające jego tożsamości - ekspansję wolnego rynku i akumulację kapitału. „Ten niełatwy związek strukturalny [suwerennego państwa i logiki kapitału - przyp. MR] stabilizowała tożsamość narodowa: tożsamość kulturalna, integrująca, oparta na biologicznej ciągłości związków krwi, przestrzennej ciagłości terytorium i wspólnocie językowej"45. Nie tylko wielość posiadała deterytorializującą moc, podobny efekt wywoływał także wolny rynek, rozpuszczając tożsamości oraz granice. Lecz choć nowoczesne państwo, by zaistnieć, musiało całkowicie odrzucić pojęcie wielości i zastąpić je ludem, to powiodło mu się jednak zintegrowanie, przynajmniej na jakiś czas, swojego aparatu z logiką rynkową. Pojęcie narodu, wiążące w transcendentną całość te konstytutywne dla tradycyjnych społeczności elementy, które ulegały najsilniejszej erozji wskutek działania kapitału (przestrzenne skupienie grupy etnicznej oraz jej językowa jednorodność), umożliwiło utrzymanie suwerenności państwa pomimo szalejącej w jego wnętrzu kapitalistycznej deterytorializacji.

Lud i naród są pojęciami związanymi z nowożytną wizją państwa jako podstawy formowania się społeczeństwa, które znosi stan natury i zaprowadza porządek. Stanowią uzasadnienie dla suwerenności władzy opartej o transcendencję i reprezentację. Wielość istnieje natomiast wyłącznie na planie immanencji, na którym walczy o zachowanie przynależnej jej władzy bezpośredniego oddziaływania na warunki swojej egzystencji. Władza ta oparta jest na tym, że wielość to przede wszystkim podmiot produkcji. Produkując,

\footnotetext{
${ }^{45}$ Tychże, Imperium, s. 111
} 
wytwarzając coraz to nowe idee, symbole, afekty i myśli, wielość wytwarza swoją rzeczywistość, nie pozwalając narzucać sobie jakiejkolwiek wyalienowanej formy życia (opór wobec reterytorializacji, np. wobec nadania tożsamości seksualnej bądź narodowej). Aby wymknąć się jednak dialektyce nowoczesności, która uparcie podporządkowywała immanentne siły wielości transcendentnemu aparatowi państwowemu, wielość musiała wpierw połączyć napędzające jej conatus idee wolności i samorealizacji z nowymi formami produkcji.

\section{Immanencja sieci produkcji niematerialnej}

Historyczne stawanie-się-wielości jest według Hardta i Negriego związane z formami pracy, jakie obowiązywały w danej epoce historycznej. $Z$ tego właśnie powodu za czasów renesansu ostatecznie nie utworzono systemu sprawowania władzy opartego na idei wielości, choć świadomość i idee do tego dojrzały (być może należałoby stwierdzić, że w tym przypadku byt nie dojrzał jeszcze do świadomości). Jeśli jednak projekt filozoficzny obu myślicieli można nazwać także projektem politycznym, to z tego tylko względu, że skupiają się oni przede wszystkim na obecnych formach i relacjach produkcji, starając się w nich odnaleźć i zdiagnozować możliwości zaprowadzenia zmiany w stosunkach władzy oraz formach rządzenia. Szansę taką wiążą z rozwojem nowej postaci produkcji, która od lat siedemdziesiątych XX wieku doprowadziła do wykształcenia się nowej hegemonicznej formy pracy: pracy niematerialnej. Jej hegemonia związana jest przede wszystkim z ekspansją sektora usługowego. W przeciwieństwie do produkcji fabrycznej, „W produkcji usług nie powstaje żadne trwale, materialne dobro" 46 . Virno z tego powodu określa pracę niematerialną jako działalność wirtuozyjną, czyli taką, która swój cel znajduje w samej sobie ${ }^{47}$. Immanentny charakter pracy niematerialnej polega zatem z jednej strony na niemożliwości oddzielenia efektu pracy od niej samej, z drugiej - na pokrywaniu się w dużym stopniu podmiotu pracy z „narzędziami” służącymi do produkcji. Praca niematerialna jest bowiem oparta przede wszystkim na aktywności intelektualnej i emocjonalnej, a nie na używaniu maszyn (energetycznych). Zgromadzona w podmiocie wiedza, wykształcone umiejętności oraz talenty zaczynają być nieporównywalnie istotniejsze od „martwej pracy” zakumulowanej w maszynach.

\footnotetext{
${ }^{46}$ Tamże, s. 310.

${ }^{47}$ P. Virno, A Grammar of the Multitude, s. 52-55.
} 
www.praktykateoretyczna.pl

W ramach pracy niematerialnej wyróżnić można trzy różne rodzaje pracy i produkcji: zinformatyzowaną produkcję przemysłową, w której maszyny energetyczne łączą się z maszynami informatycznymi, wymagając do obsługi pracownika zupełnie innego rodzaju; pracę niematerialną opartą o analizę symboli i przesyłanie informacji oraz pracę polegającą na wytwarzaniu i manipulowaniu emocjami (praca afektywna, praca opiekuńcza). Niezwykle ważny jest ten trzeci aspekt pracy niematerialnej: wytwarzanie relacji międzyludzkich, opieka nad innymi, troska o rozwój jednostek. Po pierwsze, wskazuje on na feministyczny wątek badań prowadzonych przez włoskich teoretyków, którzy starają się dostrzegać podmiot produkcji nie tylko w męskim pracowniku fabryki, lecz także w afektywnym podmiocie kobiecym $^{48}$. Po drugie (co wynika po części z pierwszego) pracy niematerialnej nie można z tego powodu postrzegać tylko jako efektu informatyzacji procesu produkcji, wytworzenia nowych rodzajów pracy etc. Przejście od hegemonii pracy materialnej do hegemonii pracy niematerialnej związane jest przede wszystkim z przesunięciem horyzontu nie-pracy, czyli z uznaniem za produkcję tych form aktywności, które dotychczas nie funkcjonowały jako produktywne. Praca niematerialna komplikuje zatem Marksowski podział na produkcję i reprodukcję społeczną, Heglowski podział na rodzinę i społeczeństwo obywatelskie oraz wszelkie teorie starające się rozdzielać relacje międzyludzkie na „naturalne” oraz „społeczne".

W paradygmatycznym tekście Immaterial Labor związany $\mathrm{z}$ czasopismem „Multitudes” Maurizio Lazzarato zwraca uwagę na relację między podmiotem pracy niematerialnej a jej przebiegiem. Wskazując na zmiany, jakie zaszły $w$ latach siedemdziesiątych (okresie narodzin postfordyzmu), stwierdza, że ,praca niematerialna w coraz większym stopniu obejmuje procedury, które mogą być definiowane jako «intelektualne», a nowe technologie komunikacji coraz bardziej wymagają subiektywności o bogatej wiedzy"49. Pierwszym efektem takiego stanu rzeczy jest postępująca autonomizacja pracownika w stosunku do konkretnego miejsca czy warunków pracy, gdyż zakumulowana w nim wiedza i umiejętności ułatwiają elastyczne funkcjonowanie na rynku pracy. W przeciwieństwie do fabryki, przedsiębiorstwo stara się ściagnąć do siebie właśnie te kreatywne, rozwinięte podmiotowości, wyrabiając $\mathrm{u}$ zatrudnionych emocjonalne relacje $\mathrm{z}$ miejscem pracy poprzez system szkoleń, konferencji, wyjazdów etc. Autonomizacja wymusza

\footnotetext{
${ }^{48}$ Nie chodzi tu o przypisanie konkretnych cech mężczyznom i kobietom, lecz o pewną diagnozę społecznego podziału pracy, w którym przez wieki to kobiety wykonywały pracę nazywaną przez nas tutaj ,afektywną” bądź „opiekuńczą”.

${ }^{49}$ M. Lazzarato, Immaterial Labor, [w:] Radical Thought in Italy: a Potential Politics, red. P. Virno, M. Hardt, Minneapolis 1996, s. 133.
} 
zatem opracowywanie nowych metod zawiązywania relacji między pracującymi a miejscem ich pracy. Przemiany, które nastappiły w Europie i Stanach Zjednoczonych po 1968 roku, spowodowały dodatkowo decentralizację miejsc produkcji kultury, która przestała być wytwarzana przez wąskie, uprzywilejowane grupy. Masowa produkcja kultury poprzedziła wyjście poza fabrykę produkcji jako takiej. Kulturą, która stanie się jednym z głównych obszarów nadchodzącego przemysłu, zaczęli się teraz aktywnie zajmować ci, którzy pozostawali wcześniej w znacznym stopniu z niej wyłączeni, prowadząc do powstania licznych, alternatywnych form życia i upodmiotowienia. „Nowy slogan społeczeństw Zachodu brzmi: wszyscy powinniśmy stać się podmiotami!"50

Praca niematerialna jest terminem obejmującym te wszystkie rodzaje aktywności, które wytwarzają relacje społeczne jako takie. Podział na relacje czysto „ekonomiczne” oraz „społeczne” jest tutaj również podawany w wątpliwość ${ }^{51}$, gdyż wartość ekonomiczną zyskują także wszelkiego rodzaju działalności „kulturalne”. Celem produkcji jest tworzenie sieci komunikacji oraz rozwijanie produkujących podmiotowości - „ulepszanie” wytwarzających jest jednocześnie „ulepszaniem” środków produkcji, gdyż produkują nie tyle ręce, co ucieleśnione umysły. Celem akumulacji kapitału staje się także „,przechwycenie” nadwyżki produkcji pracy niematerialnej w postaci swego rodzaju „wartości dodatkowej” inteligencji, doświadczenia, wiedzy czy pożądania. Produkcja niematerialna zakłada więc immanencję zarówno narzędzi produkcji (wytwarzamy tym, co konstytuuje nas jako podmioty), jak i immanencję wytworów produkcji w stosunku do społeczeństwa (produkcja wytwarza bezpośrednio substancję społeczną):

Jeśli dziś produkcja jest bezpośrednio produkcją relacji społecznych, to «surowcem» pracy niematerialnej jest podmiotowość oraz «ideologiczne» środowisko, w którym ta podmiotowość żyje i się reprodukuje ${ }^{52}$.

Materialnym warunkiem tej podwójnej immanencji jest przejście do gospodarki opartej na informacji (przejście do społeczeństwa informacyjnego w rozumieniu Manuela Castellsa $^{53}$ ), czyli masowy rozwój sieci komunikacji. Konsekwencją tego przejścia jest, podkreślę to raz jeszcze, radykalna decentralizacja produkcji ${ }^{54}$. Ponieważ każdy aspekt życia

\footnotetext{
${ }^{50}$ Tamże, s. 134 .

${ }^{51}$ M. Hardt, A. Negri, Multitude..., s. 224.

52 M. Lazzarato, Immaterial Labor, s. 142.

53 Zob. M. Castells, P. Himanen, Społeczeństwo informacyjne i państwo dobrobytu: model fiński, tłum. M. Penkala, M. Sutowski, wstęp E. Bendyk, Warszawa 2009.

${ }^{54}$ M. Hardt, A. Negri, Imperium, s. 314.
} 
www.praktykateoretyczna.pl

społecznego staje się produktywny, niepotrzebne jest tworzenie centrów fabrycznych w postaci wielkich miast przemysłowych, które nie tylko skupiałyby kapitał w postaci środków produkcji, ale także utrzymywałyby w jednym miejscu potrzebną siłę roboczą. Taśmę zastapiono siecią. O ile jednak taśma fabryczna była materialną podstawą logiki komunikacji wewnątrz fabryki, która różniła się od dróg komunikacji towarów i idei na zewnątrz, o tyle logika sieci jest immanentna zarówno wobec procesów produkcji, jak i komunikacji - czy to dystrybucji usług, czy też zawiązywania się sieci kontaktów. Zawiązywanie komunikacji oraz wytwarzanie towarów i usług stają się powoli tym samym ${ }^{55}$.

\section{Poziom drugi: od robotnika do wielości}

Decentralizacja sieci produkcji i rozlanie się fabryki na całe ciało społeczne wymuszają jednocześnie gruntowne przemyślenie takich pojęć, jak klasa (klasa pracująca), wyzysk, wartość dodatkowa, subsumcja pracy pod kapitał itd. Także w tym punkcie ograniczę się jedynie do aspektów niezbędnych dla przyjętej przeze mnie perspektywy. Najważniejsze będzie prześledzenie transformacji, którą masowy robotnik epoki fordyzmu przeszedł na drodze do ukonstytuowania się wielości.

Wielość jest formą społeczną otwartą na wszelkiego rodzaju różnicę (różne języki, rodzaje seksualności), opierającą się jednocześnie każdej formie nadawania jej tożsamości, np. w postaci obywatela państwa narodowego. W tym braku tożsamości, jak również w byciu podmiotem produkcji (niematerialnej), przypomina zasadniczo figure proletariatu z filozofii Marksa. Jednak i od niej różni się gruntownie, radykalizując postulat bycia otwartym na różnorodność. Wielość składa się z jednostek wykonujących wszelkiego rodzaju pracę, także tę, która z perspektywy Marksa nie zaliczała się do działalności produkcyjnej. W centrum

\footnotetext{
${ }^{55}$ Warto w tym miejscu odwołać się do dyskusji między Przemysławem Wielgoszem a Michałem Hererem, która była być może jedyną wartościową debatą na temat Imperium w Polsce po wydaniu polskiego thumaczenia. Wielgosz w opublikowanym w dodatku do „Trybuny” tekście Imperialna bzdura krytykuje najważniejsze tezy książki Hardta i Negriego, w tym samą koncepcje pracy niematerialnej (choć, zupełnie wbrew intencjom autorów, nazywa ją „nową gospodarką"), redukując jej hegemonię do samego rozwoju technologii informatycznych. Na ten i na pozostałe zarzuty Wielgosza (dotyczące zmierzchu państwa narodowego i końca imperializmu) odpowiedział Herer w swoim tekście Imperium kontratakuje, opublikowanym na portalu lewica.pl. Herer słusznie zwraca uwagę, że wbrew temu, co pisze Wielgosz, myśl Hardta i Negriego wywodzi się z myśli Marksa - przede wszystkim w praktyce tworzenia pojęć. To deleuziańskie podejście, widzące zadanie filozofii w tworzeniu i przetwarzaniu pojęć (swoistego rodzaju pracę niematerialną) jest jak najbardziej zgodne z intencjami autorów Imperium, którzy starają się przede wszystkim znaleźć filozoficzny słownik zdolny stworzyć dyskurs zgodny z tendencjami współczesnych procesów społecznych i ekonomicznych. W kwestii pracy niematerialnej Herer odrzuca przypisanie Hardtowi i Negriemu jakiegokolwiek rodzaju determinizmu technologicznego. Praca niematerialna nie dotyczy tyle nowych technologii, co przede wszystkim sposobu ich użycia przez subiektywności i form, które te nowe subiektywności przyjmują. Analizowane w tym tekście pojęcie „wielości” jest efektem tego genealogiczno-dekonstrukcyjno-inwecyjnego podejścia filozoficznego, które stara się nieustannie przygotowywać zmianę rzeczywistości na drodze jej interpretacji.
} 
marksowskiej myśli znajdował się wysoko wykwalifikowany robotnik, który świetnie znał się na obsłudze używanych przez siebie maszyn. Pozostawał nieufny wobec tzw. lumpenproletariatu, czyli tych wszystkich, którzy stanowili biedotę, niewykwalifikowaną siłę roboczą. Jednak, jak już to zaznaczyłem, przywołując słowa Bendyka, wielość stanowią zarówno ludzie doskonale obeznani z obsługą współczesnych maszyn informatycznych oraz zinformatyzowanych maszyn industrialnych, jak i autorzy blogów, oprogramowania freeware, stron internetowych, opiekunowie starszych, chorych, dzieci etc. - często za marne lub żadne wynagrodzenie. Wielość stanowią podmioty szeroko rozumianej pracy - pracy niematerialnej.

Finn Bowring w swoim znakomitym artykule poświęconym teoretycznemu kontekstowi pojęcia wielości z Imperium ${ }^{56}$ wyróżnia trzy etapy w historii kompozycji klasy pracującej. Pierwszy etap, od 1848 roku do pierwszej wojny światowej, to okres opisywany przez Marksa i jego bezpośrednich kontynuatorów, w którym na pierwszym miejscu lokuje się swoista ,arystokracja pracy” - ,robotnik silnie identyfikujący się z rolą «wytwórcy» i znający całość cyklu produkcji, ${ }^{, 57}$. W epoce szerzącego się imperializmu i podporządkowywania całych kontynentów interesom kilku krajów, walka w imię godności pracy i interesów (męskich) pracowników fabrycznych podporządkowała sobie - w postaci partii funkcjonującej w modelu leninowskim - całe bogactwo społecznej produktywności. W rozwijającej się wówczas teorii oraz w świadomości pracowników przeciwstawiani byli oni nie tylko klasie posiadającej środki produkcji, lecz także tym, którzy stanowili niewykwalifikowaną siłę roboczą $i$ nie posiadali stałego miejsca pracy lumpenproletariatowi.

Drugi etap rozciagga się od 1918 do 1968 roku. Strategie fordyzmu i tayloryzmu, połączone $\mathrm{z}$ postępującą automatyzacją pracy fabrycznej, doprowadziły do zaniku wykwalifikowanego robotnika, wytwarzając coś na kształt podmiotu „,pracy abstrakcyjnej”działalności określanej wyłącznie poprzez zużytkowany czas, a nie poprzez konkretne formy, jakie przyjmuje. Praca przy taśmie i powtarzanie rutynowych czynności wykształciły nie tyle „wytwórcę”, co ludzki dodatek do linii produkcyjnej, żywe paliwo dla martwej maszyny. Niczym niedoskonałe, lecz nadal niezbędne tryby w wielkich industrialnych maszyneriach, pracownicy (wciąż głównie mężczyźni) stawali się powoli całkowicie zastępowalni. Tendencja ta prowadziła jednak do coraz większej elastyczności siły roboczej, która to samo zadanie mogła wykonywać w dowolnym miejscu. Dla takich ludzi, jak Negri czy Virno,

\footnotetext{
${ }^{56}$ F. Bowring, From the Mass Worker to the Multitude: a Theoretical Contextualization of Hardt and Negri's Empire, "Capital \& Class" 2004, nr 2, s. 101-132.

${ }^{57}$ Tamże, s. 106.
} 
www.praktykateoretyczna.pl

niezwykle istotnym procesem $\mathrm{w}$ tym okresie były migracje ludności z południa Włoch do bogatej północy. Masowi pracownicy zakładów chemicznych czy samochodowych, elastyczna i mobilna siła robocza, nie identyfikowali się już $z$ typowymi formami reprezentacji, takimi jak włoska partia komunistyczna bądź związki zawodowe. Wtedy narodził się ruch Potere Operaio, a potem Autonomia, które za cel stawiały sobie polityczne upodmiotowienie nowego rodzaju pracownika masowego. Według teoretyków ruchów tamtych lat, dzięki wypracowanym wówczas metodom odmowy pracy ${ }^{58}$ udało się zrobić milowy krok na drodze uwalniania ludzi od najżmudniejszych rodzajów zajęć poprzez wprowadzanie coraz to doskonalszych zautomatyzowanych maszyn.

Trzeci etap „charakteryzuje się pod względem technologicznym wysokim poziomem komputeryzacji i automatyzacją procesu produkcji”, ${ }^{, 59}$. Praca została w jeszcze większym stopniu uniezależniona od maszyn (energetycznych, industrialnych), polegając głównie na analizie danych potrzebnych do dalszej produkcji. Produkcja za to opuściła wysokie mury fabryk i rozlała się na całe społeczeństwo - fabryka przemysłowa, paradygmatyczna dla społeczeństwa dyscypliny, przekształciła się w społeczeństwo-fabrykę, modulującą społeczeństwo kontroli za pomocą sieci jednostek funkcjonujących na wzór przedsiębiorstw. Masowy robotnik epoki fordyzmu, który stawia przede wszystkim na swoją mobilność, uniezależniając się w dużym stopniu od procesu produkcji przechodzi - poprzez automatyzację produkcji fabrycznej - podobną transformację. W epoce postfordyzmu rozwija się zapotrzebowanie przede wszystkim na pracę niematerialna, masowy robotnik fabryczny przemienia się zatem w robotnika społecznego (operaio sociale w terminologii Negriego) ${ }^{60}$, który swoją pracę wykonywać może w elastycznie dobieranym czasie i miejscu. Według Hardta i Negriego duży wpływ na te przemiany miały buntownicze hasła podnoszone od roku 1968. Uczestnikom ruchów kontrkulturowych i kontestacyjnych udało się swoimi ideami i pragnieniami wymusić zmianę struktur ekonomicznych ${ }^{61}$. Nowe, twórcze, nomadyczne ${ }^{62}$ podmiotowości stanowiły wyzwanie dla aparatów państwowych powojennego świata, jak również dla samego kapitału. Droga, którą obrano w celu stabilizacji systemu, była nastawiona na ,zmianę społecznej struktury proletariatu, a więc zintegrowanie,

\footnotetext{
${ }^{58}$ Zob. M. Tronti, The Strategy of Refusal, tekst dostępny na stronie http://libcom.org/library/strategy-refusalmario-tronti.

${ }^{59}$ F. Bowring, From the Mass..., s. 110.

${ }^{60}$ Tamże, s. 112.

${ }^{61}$ M. Hardt, A. Negri, Imperium, s. 284-293.

${ }^{62}$ Zob. R. Braidotti, Les Sujets Nomades Féministes Comme Figure des Multitudes, "Multitudes" 2003, nr 12, http://multitudes.samizdat.net/Les-sujets-nomades-feministes.
} 
zdominowanie i wykorzystanie nowych form i praktyk" ${ }^{\text {"63 }}$ wytwarzania podmiotowości. Proliferacja miejsc pracy w takich obszarach, jak „komunikacja i media, transport, edukacja, opieka zdrowotna i socjalna, finanse, reklama, rozrywka i tworzenie kultury" ${ }^{\prime 64}$, spowodowana była nie tylko rozwojem technologicznym (sieci komunikacji, informatyzacja, komputeryzacja etc.), ale także potrzebą uporania się z ludźmi pragnącymi innego życia niż to, które oferowane im było w fordystycznym reżimie dyscyplinowania społeczeństwa.

Termin „robotnik społeczny” pełni zasadniczo tę samą funkcję, którą Hardt i Negri przypisują wielości, odnosi się jednak do stricte ekonomicznego, czy mówiąc inaczej, „bazowego" aspektu analizy społeczeństwa. Wskazuje na niezwykle istotny moment konstytucji wielości, na jej bycie podmiotem produkcji niematerialnej, który to status według obu autorów uzyskano na drodze nieustannego ścierania się tendencji maksymalizowania wydajności procesu produkcji oraz dążenia pracowników do wpływania na warunki ich pracy. Spór okazał się $\mathrm{w}$ dużym stopniu sporem o automatyzację produkcji: w paradygmacie fordystycznym automatyzacja zakończyła się na taśmie produkcyjnej, przy której zredukowane do jednej czynności ciało pracownika ulegało całkowitemu odpodmiotowieniu. Automatyzacja posunięta o krok dalej (postępem technologicznym oraz aktywnością polityczna) za swój efekt miała przejście do paradygmatu postfordystycznego, w którym hegemoniczną formą pracy stała się praca niematerialna.

Mówiąc o wielości, trzeba przede wszystkim skomplikować relację między „bazą” i „,nadbudową”, „ekonomią” i „kulturą”, „rynkiem” i ,życiem” etc. Tak jak nie ma już „wnętrza” i ,zewnętrza” fabryki, lecz złożone z mikrostruktur przedsiębiorstwa, sieciowe społeczeństwo-fabryka pracy niematerialnej, tak też nie ma jednolitego proletariatu przeciwstawionego logice kapitału. Wielość to „zbieranina” wszystkich, którzy tworzą tkankę społeczna, gdyż dzisiaj tworzyć społeczeństwo oznacza produkować, a pracować - budować relacje społeczne. „Dekonstrukcji” podlega więc także przeciwstawienie proletariatu i lumpenproletariatu, gdyż trudno określić, która „klasa” czy grupa stanowi podstawę procesu produkcji. Jednym bowiem z najbardziej palących zadań obecnych czasów jest poradzenie sobie z olbrzymią przepaścią, jaka oddziela świat produkcji od świata płacy.

Jeśli więc wielość musi być rozpatrywana nie tylko w optyce dialektyki nowoczesności, lecz także z marksowskiej perspektywy żywej pracy poddawanej wyzyskowi, to należałoby znaleźć takie ujęcie wyzysku, które odpowiadałoby formom pracy wykonywanej przez wielość - wyzysk nie tylko żywej pracy, lecz form życia. Jest to już

\footnotetext{
${ }^{63}$ M. Hardt, A. Negri, Imperium, s. 288.

${ }^{64}$ Tamże, s. 111.
} 
www.praktykateoretyczna.pl

jednak zadanie wykraczające poza ramy tego studium. W tym miejscu starałem się jedynie pokazać genealogię pojęcia wielości, biegnącą od Marksowskiego proletariatu do postfordystycznego „robotnika społecznego”, zwłaszcza w relacji do zmieniającej się funkcji maszyn, od których zaczęliśmy nasze genealogiczne analizy. Kiedy więc u zarania nowoczesności wielość ujawniała się przede wszystkim na poziomie idei, teraz ,jawi się jako historyczny rezultat, dojrzały punkt dojścia przemian, które dokonały się w procesie

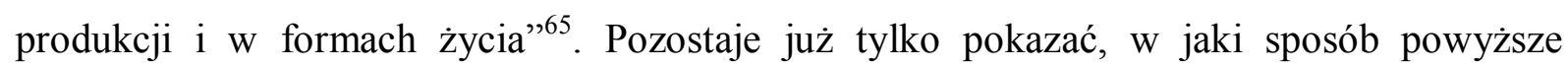
rozważania umożliwiają uznanie wielości za podmiot posiadający władzę ontologicznej konstytucji.

\section{Biopolityczna konstytucja wielości}

Pojęcie biopolityki do szerszego dyskursu filozoficznego wprowadził w latach siedemdziesiątych w swoich wykładach w Collège de France Foucault ${ }^{66}$. Odnosi się ono do sposobu, w jaki nie tyle jednostki, co całe populacje, rozumiane jako zbiorowiska żywych biologicznych istot, znalazły się w centrum mechanizmów władzy. Wiązało się to z rozwojem różnego rodzaju instytucji, których celem miało być dbanie o zdrowie i rozwój organizmów, aby populacja była nie tyle, bądź nie tylko, zbiorem posłusznych, zdyscyplinowanych ciał indywiduów, lecz przede wszystkim zdrowym, silnym ciałem społecznym, które decydowało o bogactwie państw narodowych. Foucault lokował rozwój tego rodzaju sposobów rządzenia (nazywanego przez niego także „rządomyślnością” [gouvernmentalité] ${ }^{67}$ ) w końcu osiemnastego oraz przede wszystkim w dziewiętnastym wieku, co wiązało się oczywiście z

\footnotetext{
${ }^{65}$ P. Virno, Virtuosity and Revolution: the Political Theory of Exodus, [w:] Radical Thought in Italy..., s. 200.

${ }^{66}$ Zob. przede wszystkim M. Foucault, Wola wiedzy, thum. B. Banasiak, K. Matuszewski, [w:] tegoż, Historia seksualności, wstęp T. Komendant, Warszawa 1995; tegoż, Trzeba bronić społeczeństwa: wyktady w Collège de France 1976, thum. M. Kowalska, Warszawa 1998; tegoż, The Birth of Biopolitics: Lectures at the Collège de France 1979, thum. G. Burchell, New York 2004.

${ }^{67}$ M. Foucault, Rzqdomyślność, [w:] tegoż, Filozofia, historia, polityka: wybór pism, thum. i wstęp D. Leszczyński, L. Rasiński, Warszawa 200o, s. 163-185. W tym miejscu należy poczynić istotną uwagę co do genezy neologizmu gouvernmentalité oraz jego znaczenia. Tłumaczenie „rządomyślność” interpretuje ukuty przez Foucaulta termin jako złożenie z dwóch wyrazów: „gouverner” [rządzić] oraz mentalité [mentalność, umysłowość]. Takie rozumienie łączy termin gouvernmentalité raczej $\mathrm{z}$ analizami technik dyscypliny czy technik ,ja", które - przykładem tu panoptykon bądź dyspozytyw konfesjonału - wytwarzają podmiotowość, świadomość, sumienie, samokontrolę itd. poprzez oddziaływanie na pojedyncze ciało i wpisywanie go w odpowiednio zorganizowaną przestrzeń. W przeciwieństwie do tego Thomas Lemke, idąc za sugestiami wydawców wykładów Foucaulta z Collège de France poświęconych właśnie pojęciu gouvernmentalité (tom pierwszy: Security, Territory, Population, tom drugi The Birth of Biopolitics), proponuje usytuowanie tego terminu w opozycji do teorii suwerenności jako klasycznej formy władzy. Gouvernmentalité byłaby zatem innym rodzajem rządzenia niż souveraineté [suwerenność], związanym z dyspozytywami kontroli pracującymi na populacjach, a nie jednostkach, oraz z biopolityką. $Z$ tego względu należałoby termin ten thumaczyć na polski raczej jako „rządowość”, czy „rządzeniowość”. Zob. T. Lemke, Gouvernmentalität und Biopolitik, Wiesbaden 2008, s. 13 (przypis).
} 
proliferacją dyskursów i instytucji zainteresowanych kwestiami medycznymi oraz psychologicznymi (higieną, seksualnością, dietą itd.), a także powstaniem metod statystycznych.

Różnorodne teorie odwołujące się do pojęcia biopolityki rozwijają jedno zasadnicze twierdzenie: życie jako takie, życie biologiczne bądź też całość życia społecznego, stało się w pewnym momencie (poszczególni autorzy różnią się co do jego chronologicznego usytuowania) główną stawką polityki na różnych jej poziomach; znalazło się w centrum mechanizmów władzy. Dla teorii Hardta i Negriego kluczowe jest jednak odróżnienie pojęcia biopolityki od biowładzy:

Pojęcie biopolityki [...] jest wpisane w pewną dynamikę, która wychodzi od historycznego rozszerzenia władzy sprawowanej przez państwo (w sensie rządzenia populacją) w nowoczesności i dochodzi do momentu, który ten związek wywraca. Ów moment, dla niektórych badaczy podążających za Foucaultem, był powodem, aby odróżnić biowładzę od biopolityki: odpowiednio, o biowładzy mówimy wtedy, kiedy państwo, poprzez techniki i urządzenia władzy, zapanowuje nad życiem; odwrotnie, o biopolityce mowa jest w krytycznej analizie panowania, która przyjmuje perspektywę doświadczenia upodmiotowienia, wolności, inaczej mówiąc - oddolną ${ }^{68}$.

W Imperium autorzy wiążą pojęcie biopolityki ze sferą produktywności, odrzucając tym samym Marksowskie i marksistowskie rozdzielenie bazy ekonomicznej, która odnosi się do ekonomicznej sfery pracy i produkcji oraz nadbudowy, która zasadniczo obejmuje wytwarzanie subiektywności oraz relacje władzy. Akceptują naczelny ich zdaniem cel Foucaulta, który próbował ,sprowadzić problem społecznej reprodukcji i wszystkie składowe tak zwanej nadbudowy do podstawowej, materialnej struktury, definiując ten obszar nie tylko w kategoriach ekonomicznych, lecz także kulturalnych, cielesnych, podmiotowych"69, chcą jednak pokazać, w jaki sposób cel ten można osiągnąc poprzez skupienie się na produktywnych mocach wielości. Póki praca oddzielana była od życia, póki wytwarzanie podmiotowości dokonywało się głównie w czasie wolnym od pracy, życie społeczne mas lokowało się na marginesie, który mogło opuszczać jedynie poprzez zorganizowaną działalność polityczną. Przejście do hegemonii pracy niematerialnej oznacza powolne zrównanie się pracy z życiem jako takim: cała podmiotowość pracownika wciągnięta jest w proces pracy, a wytwarzanie wartości dodatkowej zależne jest od ukierunkowanego rozwoju

\footnotetext{
${ }^{68}$ A. Negri, Zur Gesellschaftlichen Ontologie: Materielle Arbeit, Immaterielle Arbeit und Biopolitik, thum. T. Atzert, [w:] Empire und die Biopolitische Wende: die Internationale Disskusion im Anschluss an Hardt und Negri, red. M. Pieper, T. Atzert, S. Karakayali, V. Tsianos, Frankfurt-New York 2007, s. 27.

${ }^{69}$ M. Hardt, A. Negri, Imperium, s. 42-43.
} 
www.praktykateoretyczna.pl

zdolności intelektualnych i emocjonalnych jednostek. Oznaczając przez biowładzę (wbrew rozróżnieniu poczynionemu uprzednio przez Negriego) same produktywne moce życia ${ }^{70}$, Hardt i Negri stwierdzają:

Biowładza staje się czynnikiem produkcji, gdy cały kontekst reprodukcji podpada pod zasadę kapitalistyczną, to jest gdy reprodukcja $\mathrm{i}$ istotne relacje, które o niej stanowią, same stają się bezpośrednio produktywne ${ }^{71}$.

Bezpośrednio produktywne staje się więc dzisiaj to, co tradycyjnie określane było jako wartość użytkowa, sytuująca się na zewnątrz ekonomii oraz relacji władzy. Perspektywa biopolityczna zakłada, że konstytucja podmiotowości nie może dokonywać się już poprzez walkę o to, co zewnętrze (np. czas wolny od pracy), lecz musi zamknąć się całkowicie wewnątrz rzeczywistości rynku, kapitału etc. Immanencja, stanowiąca ontologiczny plan bytu wielości, zlewa się z immanencją przepływu kapitału, a podporządkowanie subiektywności zaczyna być nieodróżnialne od konstytucji podmiotu w oparciu o opór, wolę sprzeciwu i pragnienie wolności.

Czy to poprzez systemy nieustannych szkoleń, wyciąganie wartości użytkowej z informacji o tym, czego szukamy w Internecie, z mobilizowania pragnień, marzeń i ambicji czy przez kontrolę sieci komunikacji, nowe reżimy kontroli nauczyły się czerpać zysk z każdego przejawu społecznych praktyk. Pozostawiając z boku dyskusję o autonomii życia wobec kapitału i aparatów władzy (a więc pytanie, czy to one wytworzyły biopolityczne moce życia, czy to raczej moce te były zawsze przez nie tłamszone), dochodzimy do twierdzenia, że usytuowanie się życia w centrum polityki autorzy Multitude rozumieją jako stawanie się produktywnym każdego momentu życia społecznego.

W terminach filozofii potencjalności to samo przejście stara się wyeksplikować Virno, kiedy wiąże perspektywę biopolityczną - podobnie jak Hardt i Negri - z pojęciem żywej pracy i siły roboczej. Najważniejsza różnica, jaka zaszła według Virna wraz z przejściem od fordyzmu do postfordyzmu, polega na tym, że ,pojęcie siły roboczej nie może być już zredukowane (jak to było w czasach Gramsciego) do agregatu fizycznych i mechanicznych atrybutów; zamiast tego, jak najbardziej słusznie, obejmuje teraz «życie umysłu»,72. Siła

\footnotetext{
${ }^{70}$ Niekonsekwencja związana z użyciem terminu „biowładza” w pismach Hardta i Negriego związana jest moim zdaniem z faktem, że odróżniając biowładzę od biopolityki, wskazują oni przede wszystkim na alternatywę tkwiącą w projekcie filozoficznym Foucaulta, natomiast przeciwstawiając biowładzę Imperium produktywnej biowładzy wielości, odwołują się do opozycji władzy ukonstytuowanej oraz władzy konstytuującej.

${ }^{71}$ M. Hardt, A. Negri, Imperium, s. 385.

72 P. Virno, The Grammar of the Multitude, s. 81.
} 
robocza to przede wszystkim czysta potencjalnośc ${ }^{73}$, która aktualizowana jest przez zaprzęgnięcie jej do konkretnych zadań. Skoro dzisiaj produkcja polega na kooperacji i pracy intelektualnej oraz emocjonalnej, aktualizacja dotyczy - jak zauważyliśmy wcześniej całości życia jednostki. Perspektywa Hardta i Negriego, gdy mówią oni o podporządkowaniu życia społecznego procesowi produkcji, jest perspektywą bardziej ogólnospołeczną. Virno (a także, w pewnym stopniu, Lazzarato) ukazuje raczej wymiar antropologiczny oraz jednostkowy. Niemniej jednak oba podejścia prowadzą do tego samego miejsca, w którym pojęcie biopolityki i Foucaultowski projekt krytyki społecznej zbiegają się w analizie nowych form pracy i nowej relacji między pracą a podmiotowością pracujących.

Ta konstatacja ma dla Virna dużo istotniejszy wymiar filozoficzny. Nie tylko każdy aspekt życia jednostki może być teraz potencjalnie podporządkowany pracy - dokonuje się także istotowa zmiana tych rodzajów aktywności, które w przeszłości zasadniczo się od pracy różniły. Przywołując teorię Arendt z jej książki Kondycja ludzka, Virno problematyzuje zasadność oddzielania pracy od działalności politycznej oraz intelektualnej ${ }^{74}$ :

Twierdzę, że postfordowska praca, nadwyżka produktywnej, podporządkowanej pracy, wykorzystuje talenty i zdolności, które zgodnie z tradycją sekularną więcej mają wspólnego z aktywnością polityczną $^{75}$.

Virno tłumaczy to nową relacją jaka zachodzi między wytworem i procesem pracy oraz między wykonującym pracę a innymi, z którymi zawiązana zostać może nić porozumienia i kontaktu. Używając wcześniej pojęcia wirtuozerii, starałem się pokazać, w jaki sposób praca niematerialna spełnia się w samym swoim procesie - efekt pracy jest niemożliwy do oddzielenia od niej samej. Ta autoteliczność pozostawała zawsze cechą odróżniającą od pracy zarówno aktywność polityczną, jak i intelektualną (praxis od poiesis), które to odróżnienie przestało już dzisiaj powszechnie obowiązywać. Angażując w proces pracy zdolności intelektualne, postfordyzm tym bardziej zatarł różnicę między pracą i działalnością intelektualną, kładąc nacisk nie tyle na powtarzanie tych samych czynności, co waloryzując przede wszystkim innowacyjność.

Obok wirtuozerii współczesna forma pracy dzieli z aktywnością artystyczną (oraz polityczną, intelektualną etc.) także inną cechę: performatywność, która oznacza konieczność istnienia grupy odbiorców podczas wykonywania określonej czynności. Virno łączy

\footnotetext{
${ }^{73}$ Tamże.

74 Tamże, s. 49-71.

${ }^{75}$ Tamże, s. 51.
} 
www.praktykateoretyczna.pl

performatywność pracy niematerialnej z jej językowym charakterem, który staje się dzisiaj niezbędny, by w sieciach komunikacji wykonać jakiekolwiek zadanie:

Język jest «pozbawiony produktu końcowego». Każda wypowiedź jest wirtuozyjnym występem [performance]. Jest to spowodowane również tym, że wypowiedź związana jest oczywiście (bezpośrednio lub nie) z obecnością innych. Język zakłada i jednocześnie ustanawia na powrót «publicznie zorganizowaną przestrzeń», o której mówi Arendt ${ }^{76}$.

Ponieważ do produkcji społecznej zaprzęgnięty zostaje sam moment antropogenetyczny - moment, w którym zwierze z gatunku homo sapiens wchodzi w rzeczywistość języka, stając się człowiekiem - produkcja staje się z istoty biopolityczna. Nie chodzi już tylko o zbiegnięcie się pracy z życiem, lecz o transformację, jakiej to drugie podlega. Funkcjonując w instytucjach poprzedzających epokę postfordyzmu (według Arendt zwłaszcza w starożytnej Grecji) moment antropogenetyczny rozgrywał się w wymienionych wyżej trzech rodzajach działalności. Kiedy omawiałem przejście od społeczeństwa dyscypliny do społeczeństwa kontroli, stwierdziłem, że w społeczeństwie kontroli (postfordyzmie) wytwarzanie podmiotowości nie dokonuje się już w zamkniętych formach odlewniczych, lecz w swego rodzaju nie-miejscu kontroli, władzy i oporu. Przemianę tę możemy określić ogólnie jako swego rodzaju dekonstrukcję granic oddzielających poszczególne ujarzmiające przestrzenie - obszary i instytucje nadające konkretne tożsamości i formy subiektywności. Pojawienie się opisywanego przez Hardta i Negriego nie-miejsca oznacza decentralizację procesu ujarzmienia, co prowadzi do wytwarzania podmiotowości pozbawionych w coraz większym stopniu wyraźnych i spójnych tożsamości. Virno dodaje do tego przejścia zlanie się trzech rodzajów upodmiotowienia, które dzisiaj zbiegają się w nowych formach produkcji i pracy.

Oba te procesy - dekonstrukcja form odlewniczych oraz przemieszanie się pracy, aktywności politycznej i działalności intelektualnej - wymuszają rozważenie tego, jak przebiega i może przebiegać we współczesności upodmiotowienie na drodze aktywności politycznej i społecznej. Obok alienacji przestrzeni politycznej - diagnozowanej przez różnych teoretyków jako zamknięcie się sfery polityki w systemie autopoietycznym czy zanik w mechanizmie demokratycznej reprezentacji konstytutywnego dla polityczności antagonizmu - należy głęboko przemyśleć, w jaki sposób dokonuje się dzisiaj

\footnotetext{
76 Tamże, s. 55.
} 
upodmiotowienie, zawiązywanie wspólnoty oraz emancypacja na poziomie mikropolitycznym, biopolitycznym.

$\mathrm{Z}$ jednej bowiem strony ,nie ma nikogo tak biednego jak ten lub ta, który/która widzi swoją własną zdolność nawiązania do «obecności innych» lub swoje posiadanie języka zredukowane do pracy zarobkowej",77, czyje upodmiotowienie jako jednostki myślącej i czującej odbywa się w całości w ramach narzuconych mu i jej warunków pracy. Z drugiej jednak, fakt, że praca dzisiaj rozwija twórcze moce, ambicje i pragnienia pracujących - czy to poprzez wykorzystywanie ich zdolności do nauki, czy też poprzez kładzenie silnego nacisku na kreatywność - oraz to, że przebiega w sieciach komunikacji, jest istotnym novum, które musi znaleźć się w centrum refleksji filozoficznej.

\section{Produkcja wspólnotowości: podsumowanie i próba krytyki}

Pojęcie wielości pełni w dyskursie filozofii politycznej (tak jak opozycyjne wobec niego idee klasycznej filozofii polityki) trzy funkcje. Po pierwsze, służy filozoficznej krytyce zastanej siatki pojęciowej, która $\mathrm{w}$ danym momencie historycznym jest do dyspozycji zarówno myślicieli, jak i polityków. Krytyka ta w wypadku pojęcia wielości nie ma jednak statusu konstrukcji (aksjomatów, zasad, podstawy), lecz raczej dekonstrukcji, ukazującej zawarte w (wybranych) dyskursach o ludzie, narodzie czy klasie procesy wykluczania oraz mechanizmy przemocy. Zasadniczo można powiedzieć, że dyskursy te mogły się ugruntować tylko poprzez akt wyparcia wielości, krążącej niczym widmo po nowożytnej Europie.

Po drugie, pojęcie to służyć może jako narzędzie diagnozowania zachodzących we współczesności przemian, oferując język łączący analizy ekonomiczne, socjologiczne, kulturoznawcze itd. z dyskursem filozoficznym, który wciąż strukturyzuje nasze myślenie o sposobach funkcjonowania w rzeczywistości (i jej zmienianiu). Zwłaszcza Virna krytyka podziału na pracę, teorię i aktywność polityczną zdaje się być istotna dla rozważań o znaczeniu, jakie przejście do postfordyzmu może mieć dla filozofii i jakie refleksja filozoficzna może mieć dla kierunku dalszego rozwoju postfordyzmu. Wielość wydaje się być pojęciem kluczowym dla współczesnych teorii antropologicznych czy teorii podmiotu, ponieważ odnosi się do konstatacji, iż miejsce wytwarzania, wzmacniania, kształtowania i wykorzystania subiektywności pokrywa się dziś praktycznie z całą rzeczywistością społeczną. Pojęcie biopolityki okazało się być przydatne, zarówno dla Virna, jak dla Hardta i Negriego,

\footnotetext{
${ }^{77}$ Tegoż, Virtuosity and Revolution..., s. 193.
} 
www.praktykateoretyczna.pl

do opisu tej nowej rzeczywistości. Przyjmując perspektywę biopolityczną, zrewidowali oni nie tylko pojęcia, ale także samą perspektywę teorii opartych chociażby na pojęciu klasy (takich jak marksizm), gdyż zmusili dyskurs filozoficzny do ponownego przemyślenia - w obliczu form, jakie przyjmują dzisiaj praktyki społeczne - takich opozycji jak bazanadbudowa, ekonomia-praktyki symboliczne itd.

Dla omawianych autorów najważniejszą funkcją pojęcia wielości jest trzecia $\mathrm{z}$ zapowiadanych - jej potencjał budowania nowego dyskursu politycznego, zawiązywania nowych łańcuchów ekwiwalencji. Dekonstrukcja filozoficznej siatki pojęciowej oraz diagnoza biopolitycznej konstytucji wielości powinny służyć odkryciu potencjału, jaki tkwi w nowych formach życia. Potencjał ten polega według mnie na fakcie, iż we współczesności w centrum społecznego życia stoi produkcja samej wspólnotowości. Poprzez „centrum społecznego życia” rozumiem dominujące formy pracy i aktywności, które w tym tekście ujęto w jednym pojęciu pracy niematerialnej. Hegemoniczna rola pracy niematerialnej, choć wiąże się z rozwojem sektora usługowego, oznacza przede wszystkim transformację wszelkich rodzajów pracy poprzez zwiększony udział wiedzy oraz informacji w bezpośrednim procesie produkcji dóbr, czy to w przedsiębiorstwie, fabryce, czy nawet na polu $^{78}$. Hegemonia pracy bazującej na pozyskiwaniu, obróbce oraz przekazie informacji, a także emocji oraz pragnień, oznacza wytwarzanie substancji społecznej w bezpośredniej produkcji dóbr. Proces ten opisaliśmy wcześniej jako immanencję pracy i jej milieu - sieci komunikacji - oraz immanencję wytworu pracy w stosunku do jej procesu (wirtuozyjność). Należałoby tu jednak zaznaczyć, że produkowane są dzisiaj nie tyle konkretne wspólnoty, co raczej sama wspólnotowość, którą tutaj rozumiem jako materialne warunki zawiązywania się komunikacji, warunku wszelkiej wspólnoty. Przedsiębiorstwo nie jest jeszcze wspólnota, lecz wytwarza wspólnotowość, dając pojedynczościom do dyspozycji narzędzia oraz czas do tego, by zawiązywać liczne relacje społeczne. Jak ujmują to Hardt i Negri, „wielość pracowników jest coraz dokładniej połączona kategoriami komunikacji oraz kooperacji (pracy, interesu oraz języka)"79. Produkuje się nowe języki i symbole, które służą wyrażaniu coraz to innych myśli oraz uczuć, a rozwijający się błyskawicznie Internet swoją innowacyjnością w zakresie narzędzi komunikacji o lata świetlne wyprzedza poprzedzające go chronologicznie media. Wspólnotowość jest zbiorczym określeniem na efekty pracy niematerialnej bądź na formę,

\footnotetext{
${ }^{78} \mathrm{~W}$ kwestii relacji między pracą niematerialną a rolnictwem czy właściwie kulturą rolniczą zob. M. Hardt, A. Negri, Multitude..., s. 115-127.

${ }^{79}$ Tychże, Labor of Dionysus..., s. 274-275.
} 
jaką przybiera życie podporządkowane w całości zasadzie kapitału. Wspólnotowość jest planem konstytucji wielości, na którym istnieje jako pełna możliwości wirtualność.

Należałoby się zastanowić, czy warto wprowadzać rozróżnienie na wspólnotowość oraz wspólnotę, zwłaszcza że to ostatnie pojęcie zdaje się już być całkowite nieadekwatne do jakiegokolwiek opisu dzisiejszego świata. Proponując jednak takie rozróżnienie, chciałbym jedynie zwrócić uwagę na obecną już moim zdaniem także w myśli Virna oraz Hardta i Negriego tendencję do nieutożsamiania ze sobą warunków powstawania wielości z nią samą. Hegemonia pracy niematerialnej jest warunkiem konstytucji wielości, a immanencja sieci komunikacji jedynie jej ontologicznym planem. Nie oznacza to, że plan ten pozbawiony jest jakiejkolwiek formy kontroli czy relacji władzy. Dlatego też wielość posiada także funkcję projektu politycznego - jest teorią podmiotu polityki rozgrywającej się w płynnej rzeczywistości kapitału zasilanego przede wszystkim pracą niematerialną (nazywanego również kapitałem kognitywnym).

Biopolityczna konstytucja wielości, czyli fakt całkowitego podporządkowania życia społecznego zasadzie kapitału oraz związane $\mathrm{z}$ tym faktem przekształcenia form upodmiotowienia, jest $\mathrm{w}$ takim samym stopniu zagrożeniem, co szansą. Immanencja współczesnych form sprawowania władzy, organizacji pracy, charakteru tej pracy etc. może spowodować, że wielość utrzymywać się będzie wyłącznie na poziomie samych swoich możliwości, na którym to poziomie może być równie skutecznie kontrolowana. Czym jest bowiem sama potencjalność, jeśli nie zmobilizuje się jej do działania? Diagnoza stwierdzająca, że wielość sama produkuje wspólnotowość, jest warunkiem rozwinięcia pozytywnego pojęcia biopolityki, o którym mówił Negri - perspektywy emancypacji i woli oporu. Perspektywa ta moim zdaniem powinna jednak wychodzić od zachodzacych w każdym miejscu przestrzeni społecznej aktualizacji potencji zawartej w produkowanej wspólnotowości. Aktualizacje te nie są już podporządkowane strukturze form odlewniczych czy istocie działania politycznego - mają one miejsce w nie-miejscu wyzysku oraz oporu. Ale miejsce to mają.

Polityka wielości to diagnoza wszelkich deterytorializujących ruchów kapitału, które jednocześnie wytwarzają nowe formy podporządkowania oraz przestrzenie wyzwolenia. Jeśli jednak ma ona służyć zadaniu emancypacji, powinna skupić się na tym, w jaki sposób produkowana dzisiaj masowo substancja społeczna może zostać wykorzystana przez swoich wytwórców. W jaki sposób wielość może stać się nie tylko podmiotem wytwarzającym wspólnotowość, ale także podmiotem wspólnoty bazującej na istniejących sieciach komunikacji. Najważniejsze pytanie dotyczy tego, czy polityka ta powinna stawiać sobie za 
www.praktykateoretyczna.pl

cel ostateczne przezwyciężenie i odrzucenie kapitalizmu (jak by to widział z pewnością, komunista Negri), czy raczej akceptację tego, że

Kapitalizm sam w sobie jest rewolucyjny, ponieważ nie ustaje w powiększaniu nierówności i prowokowaniu niepokojów. Nie ustaje także w zaprowadzaniu specyficznego dla siebie «komunizmu», zarówno jako szczepionki, zapobiegającej dalszemu rozrostowi, jak i bodźca, by przekraczać swoje własne ograniczenia. Wielość reaguje na jedno i drugie, mogąc albo tłumić wstrząsy, albo zwielokrotniać pojawiające się w nieprzewidywalny sposób pęknięcia ${ }^{80}$.

Mikołaj Ratajczak, Multitude: production of the common

Summary: The paper is an attempt to reconstruct the notion of multitude which appears in the work of Antonio Negri, Michael Hardt and Paolo Virno. Multitude refers to the emergence of a new social subject, substantially different from the known historical formulations (nation, people, class). The notion is analyzed both in the context of the classical political philosophy and the changes in the modes of production occuring in the western societies - transition from the material to immaterial labor, which consists of producing relations between social singularities. The genealogical perspective will be therefore supplemented by the analysis of the biopolitical constituion of the multitude and both perspectives will show the exigency to deconstruct numerous notions of the traditional philosophy.

Key words: multitude, immaterial labor, biopolitics, production of subjectivity, immanence of net, discipline, society of control, globalization, empire, deterritorialization, deconstruction, composition of labor class, Negri, Hardt, Virno, Lazzarato, Foucault.

\footnotetext{
${ }^{80}$ S. Lotringer, We, the Multitude, s. 18.
} 